\begin{abstract}
ARTICLES
Gubernatorial Emergency Management Powers: Testing the Limits in Pennsylvania

Patricia Sweeney, JD, MPH, RN and Ryan Joyce, JD*
\end{abstract}

\title{
I. INTRODUCTION
}

We live in an age marked by natural disasters, pandemics, and terrorism. Individually and in combination, these destructive forces provoke sociopolitical and economic havoc across the country. Pennsylvanians are intimately familiar with the devastating effects of flooding, severe tornadoes, and crippling snowstorms. Moreover, the very landscape of Pennsylvania bears the scars of the wreckage of a failed terrorist airplane hijacking. Such disasters, be they attributable to nature or humankind, present unique challenges to state and local governments. During such crisis, officials-from small-town mayors to the Governor - are called upon to make critical, timesensitive decisions. Some of these decisions will be wise and prove effective, while others may not. Against this backdrop of seemingly impending crisis, it is critical that the legal powers of elected officials be clearly understood before they are needed.

This article explores one such disaster-related legal issue by answering the question: When the Governor of Pennsylvania declares a state of emergency, what are his emergency management powers, and what is the breadth of the scope of these powers? Answering this question requires an understanding of state governors' powers in general, which is presented in

Patricia Sweeney is the Health Commissioner for the Mahoning County Board of Health and an Assistant Professor at the University of Pittsburgh Graduate School of Public Health. Ryan Joyce is a 2010 graduate of the University of Pittsburgh School of Law and an Associate at Swartz Campbell, LLC. 
Volume 6 Issue 2

Spring 2012

Part II of the article. Part III discusses the constitutional and statutory authority for the Pennsylvania Governor's emergency management powers. The apparent breadth of these powers is explored in Part IV, wherein the Governor's powers are analyzed in the context of legislative history. Part V analyzes effective "checks" on the Governor's powers and details a specific instance of a legal challenge to the Governor's declaration of a state of emergency. Part VI concludes with the answer to the central inquiry.

\section{General Emergency Management Powers of State GOVERNORS}

As a state's chief executive officer, "its governor is primarily responsible for protecting the public safety and welfare of the people of that state ...."1 Gubernatorial duties and powers with respect to the protection of the "public safety and welfare" are prescribed by a state's constitution and statutes. ${ }^{2}$ The duties and, in particular, powers of governors in terms of emergency management are of special importance and, as a corollary, the subject of some debate. While the general consensus is that state governors possess "extraordinary" ${ }^{3}$ or even "sweeping" ${ }^{4}$ emergency management powers during declared emergencies, "[e]mergency powers are not absolute."

"Reflecting their leading role in disaster response, governors are granted emergency powers to fulfill their responsibilities in extraordinary

${ }^{1}$ David A. Trissell \& Diane Donley, Coordinated Federal Emergency Responses within the National Response Plan, in A LEGAL GUIDE TO HOMELAND SECURITY AND EMERGENCY MANAGEMENT FOR STATE AND LOCAL GOVERNMENTS 151 (Earnest B. Abbott \& Otto J. Hetzel eds., 2006).

238 AM. JUR. 2D Governor $§ 4$ (2009).

${ }^{3}$ Trissell \& Donley, supra note 1, at 151.

${ }^{4}$ William C. Nicholson, EMERgENCY Response and EMERGENCY MANAGEMENT LAW: CASES AND MATERIALS 213 (2003).

${ }^{5}$ NATIONAL GOVERnors Association CENTER for Best Practices, THE GOVERNOR's GUIDE TO HOMELAND SECURITY 14 (2007) [hereinafter NGA, GOVERNOR's GUIDE], available at http:/www.nga.org/files/live/sites/ NGA/files/pdf/0703GOVGUIDEHS.PDF. 
circumstances." ${ }^{6}$ The range of powers includes: suspending state statutes and regulations; ordering evacuations; commandeering the use of private property; controlling access to disaster sites; rationing supplies such as food, water, and fuel; implementing specific public health response measures; and authorizing emergency funds without prior legislative consent. ${ }^{7}$ In order to invoke such powers, a governor must declare a state of emergency, usually through issuance of an executive order or a proclamation. ${ }^{8}$

\section{SOURCES OF CONSTITUTIONAL AND STATUTORY AUTHORITY FOR THE PenNSYlVANia GovernoR'S EMERgenCy MANAGEMENT POWERS}

The Governor of Pennsylvania, like all state governors, derives broad authority from the state's Constitution. The Constitution of the Commonwealth of Pennsylvania vests "supreme executive power" in the Governor and directs him to "take care that the laws be faithfully executed." 9 The Governor functions as "commander-in-chief of the military forces of the Commonwealth ...." ${ }^{10}$ The Governor may appoint officers, ${ }^{11}$ pardon criminals, ${ }^{12}$ and approve or veto bills sent to him by the General Assembly. ${ }^{13}$

${ }^{6} I d$.

${ }^{7} I d$.

${ }^{8} I d$. "The authority for executive orders is found in both state constitutions and state statutes, or is implied by the powers assigned to the governor." See NGA, GOVERNOR's GuIDE, supra note 5. In at least seven states, the authority for issuing executive orders and proclamations has been supplemented by case law. See Council of State Governments, The BOOK OF THE STATES 192 tbl. 4.5 (2009).

\footnotetext{
${ }^{9}$ PA. CONST. art. IV, $\S 2$.

${ }^{10}$ PA. CONST. art. IV, $\S 7$.

${ }^{11}$ PA. CONST. art. IV, $\S 8$.

${ }^{12}$ PA. CONST. art. IV, $\S 9$.

${ }^{13}$ PA. CONST. art. IV, $\S 15$.
} 


\section{Volume 6 Issue 2}

Spring 2012

It is noteworthy that the Constitution does not expressly authorize the issuance of executive orders and proclamations. ${ }^{14}$

The Governor of Pennsylvania assumes his emergency management powers under specific provisions of the Emergency Management Services Code ("the Code"). ${ }^{15}$ One of the stated purposes for the Code is to "[c]larify and strengthen the role[] of the Governor ... in prevention of, preparation for, response to and recovery from disasters." ${ }^{16}$ Furthermore, the Code announces that it does not intend to "[1]imit, modify or abridge the authority of the Governor to proclaim martial law or exercise any other powers vested in him under the Constitution, statutes or common law of this Commonwealth."17

Section 7301, entitled "General authority of Governor," addresses emergency declarations and the Governor's emergency management powers. ${ }^{18}$ The Governor is designated as the State's foremost first responder and is thus "responsible for meeting the dangers to this Commonwealth and people presented by disasters." ${ }^{19}$ The Governor is empowered to "issue ... executive orders [and] proclamations" ${ }^{20}$ for the purpose of declaring a

${ }^{14}$ See Shapp v. Butera, 348 A.2d 910, 912 (Pa. Commw. Ct. 1975) ("There is no mention in the Constitution of 'Executive Orders'."). But see 35 PA. CONS. STAT. $§ 7301$ (b) (2011) ("Under this part, the Governor may issue, amend and rescind executive orders, proclamations and regulations ....").

\footnotetext{
1535 PA. CONS. STAT. §§ 7101-04 (2011).

${ }^{16} 35$ PA. CONS. STAT. § 7103(4) (2011).

1735 PA. CONS. STAT. § 7104(3) (2011).

1835 PA. CONS. STAT. § 7301(a) (2011).

1935 PA. CONS. STAT. § 7301(a) (2011).
}

2035 PA. CONS. STAT. §7301(b) (2011). The executive order or proclamation must "indicate the nature of the disaster, the area or areas threatened and the conditions which have brought the disaster about ...." Id. at $\S 7301$ (c). The order or proclamation must be "disseminated promptly by means calculated to bring its contents to the attention of the general public," and a copy must be filed with the Pennsylvania Emergency Management 
"disaster emergency," when a "disaster has occurred or . . the occurrence or the threat of a disaster is imminent." ${ }^{21}$ Absent the Governor's renewal, the declaration of a disaster emergency automatically terminates after 90 days. Alternatively, the General Assembly may terminate a state of emergency at any time. $^{22}$

Subsection (f) of 7301 specifically enumerates the emergency management powers conferred upon the Governor by the Code. The Governor may:

(1) Suspend the provisions of any regulatory statute prescribing the procedures for conduct of Commonwealth business, or the orders, rules or regulations of any Commonwealth agency, if strict compliance with the provisions of any statute, order, rule or regulation would in any way prevent, hinder or delay necessary action in coping with the emergency.

(2) Utilize all available resources of the Commonwealth Government and each political subdivision of this Commonwealth as reasonably necessary to cope with the disaster emergency.

(3) Transfer the direction, personnel or functions of Commonwealth agencies or units thereof for the purpose of performing or facilitating emergency services.

Agency (PEMA). Id. The order or proclamation has the "force and effect of law." Id. at $\S 7301(b)$. See Pa. Dep't of Health v. N. Hills Passavant Hosp., 674 A.2d 1141, 1146 (Pa. Commw. Ct. 1996) (holding that "an executive order authorized by statute and intended to implement or supplement that statute has the force of law."). See 37 Pa. Bull. 1957 (Apr. 28, 2007), available at http://www.pabulletin.com/secure/data/vol37/37-17/731.html (providing an example of a proclamation of disaster emergency issued by the Pennsylvania Governor).

${ }^{21} 35$ PA. CONS. StAT. § 7301(c) (2011). See also 35 PA. Cons. STAT. $\S 7102$ (2011) (defining a disaster emergency).

2235 PA. CONS. STAT. § 7301(c) (2011). 
(4) Subject to any applicable requirements for compensation under section 7313(10) (relating to powers and duties), commandeer or utilize any private, public or quasi-public property if necessary to cope with the disaster emergency.

(5) Direct and compel the evacuation of all or part of the population from any stricken or threatened area within this Commonwealth if this action is necessary for the preservation of life or other disaster mitigation, response or recovery.

(6) Prescribe routes, modes of transportation and destinations in connection with evacuation.

(7) Control ingress and egress to and from a disaster area, the movement of persons within the area and the occupancy of premises therein.

(8) Suspend or limit the sale, dispensing or transportation of alcoholic beverages, firearms, explosives and combustibles. $^{23}$

Subsequent sections of the Code grant the Governor the following additional authority: "to enter into purchase, lease or other arrangements with any Federal agency for temporary housing units" and "[to] assist any political subdivision of this Commonwealth ... to acquire sites necessary for such temporary housing ... by advancing or lending funds" appropriated for any purpose by the General Assembly or to "pass through" funds furnished by "any agency, public or private",24 "to clear or remove from publicly or

2335 PA. CONS. STAT. § 7301(f) (2011). Note that subparagraph (1) specifically authorizes the Governor to "suspend the provisions of any regulatory statute" as conditions necessitate. Id. (emphasis added). A discussion of what distinguishes a regulatory statute from other types of statutes or statutes in general appears later in this memo. See discussion infra Part V.A.

${ }^{24} 35$ PA. CONS. STAT. $§ 7302(a)(1)-(2)$ (2011). 
privately owned land or water, debris and wreckage which may threaten public health or safety, or public or private property," through the use of Commonwealth agencies or instrumentalities; ${ }^{25}$ "to apply to the Federal Government, on behalf of [a] political subdivision, for a loan and to receive and disburse the proceeds of any approved loan to any applicant political subdivision; ${ }^{26}$ to accept and disburse Federal dollars "to meet disaster-related necessary expenses or serious needs of individuals or families." ${ }^{27}$ Finally, the Code establishes the Pennsylvania Emergency Management Agency (PEMA) to oversee and implement a statewide civil defense and disaster relief program. ${ }^{28}$ The Governor heads the Agency's Council and has the power to appoint the Agency's Director as well as various representatives to serve as nonvoting members of the Council. ${ }^{29}$

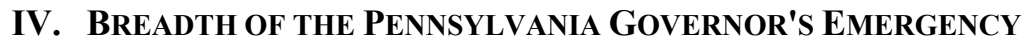 MANAGEMENT POWERS}

The plain language of the Code evinces the expansive scope of the Governor's emergency management powers. A manifest legislative purpose behind the Code is to "strengthen the role[] of the Governor . . . in prevention of, preparation for, response to and recovery from disasters." ${ }^{30}$ Thus, the Code aims to delineate and bolster the Governor's powers vis-à-vis the entire arc of emergency management, from prevention efforts to mitigation and recovery measures. In a section entitled "Limitations," the General Assembly emphasized that the Code in no way circumscribes the usual powers vested in

2535 PA. CONS. STAT. § 7303(a)(1) (2011).

${ }^{26} 35$ PA. CONS. STAT. § 7304(1) (2011) (This authority arises only when the Governor requests the President to declare a major disaster in the Commonwealth.).

2735 PA. CONS. STAT. § 7305(b) (2011) (This authority arises only when those individuals or families have been adversely impacted by a major disaster declared by the President.).

\footnotetext{
2835 PA. CONS. STAT. § 7311 (2011).

2935 PA. CONS. STAT. § 7312(a), (e) (2011).

${ }^{30} 35$ PA. CONS. STAT. § 7103(4) (2011) (emphasis added).
} 


\section{Volume 6 Issue 2}

Spring 2012

the Governor under the Constitution, statutes, regulations, or common law of the Commonwealth. ${ }^{31}$ Finally, as noted above, Subsection (f) of 7301 and subsequent sections of the Code grant the Governor overarching authority to suspend the operation of some laws, order evacuations, commandeer property, and pursue other extraordinary measures in the interest of "meeting the dangers to this Commonwealth and people presented by disasters." ${ }^{32} \mathrm{~A}$ review of legislative history behind the Code does not militate against a broad interpretation of the Governor's emergency management powers. ${ }^{33}$ The Code was introduced on September 27, 1977, as Senate Bill 1104, ${ }^{34}$ sponsored by Senators Mellow, Kury, McKinney, Sweeney, Early, Ross, and Holl. ${ }^{35}$ Senator Kury addressed the Senate the following week, stating that the impetus behind the Bill was a joint study of the Committee on Environmental Resources and the Committee on Consumer Affairs investigating "the energy

3135 PA. CONS. STAT. § 7104(3) (2011).

3235 PA. CONS. STAT. § 7301(a), (f) (2011).

${ }^{33}$ Researching the legislative history of Pennsylvania's statutes is notoriously difficult and typically yields little.

\begin{abstract}
Many of the types of documents that are available for compiling a complete legislative history on the federal level are just not available in Pennsylvania. Hearings are not published and in most situations committee reports are not distributed. ... [I]n most instances the researcher has no option but to look at floor debate from the House and Senate.
\end{abstract}

Marc Silverman, Pennsylvania Research: Primary Sources, LEGISLATIVE AND ADMINISTRATIVE MATERIALS, BARCO LAW LIBRARY RESEARCH GUIDES, http://www.law.pitt.edu/library/paresearch (follow "Legislative and Administrative Materials" hyperlink) (last visited Jan. 25, 2012).

${ }^{34}$ S. 1104, 161st Gen. Assemb., Reg. Sess. (Pa. 1978).

${ }^{35}$ Bill Information: Senate Bill 1104, Pennsylvania General ASSEMBLY, http://www.legis.state.pa.us/cfdocs/billinfo/bill_history.cfm? syear $=1977 \&$ sind $=0 \&$ body $=S \&$ type $=B \& b n=1104$ (last visited Jan. 25, 2012). 
crisis of the winter of 1977." ${ }^{36}$ The Senator urged his colleagues to deliberate quickly so that the legislation would be enacted "before the cold hits us again this winter." ${ }^{37}$ The only notable resistance to the Bill came from Senator Tilghman who took issue with Section $7503,{ }^{38}$ wherein municipalities are required to make substantial outlays for, inter alia, a fully equipped and staffed "emergency operations center." ${ }^{39}$ According to Senator Tilghman, the Section would have the effect of "mandating ... extremely heavy costs on every political subdivision in the Commonwealth ...." Tellingly, no Senator objected to any provision for the broad grant of the Governor's emergency management powers.

The most substantive remarks on the House floor came from Representative DeMedio who independently and simultaneously drafted legislation (House Bill 1635) designed to "correct deficiencies in disaster planning and control ...." ${ }^{41}$ Seeing the Bills as having a strikingly "similar [] purpose" and noting that "the Senate Bill ha[d] cleared the Senate," he retired his Bill and fully supported the Senate Bill. ${ }^{42}$ Representative DeMedio announced: "The essential object of the [C]ode is to make provisions for powers and duties of state and local government bodies and agencies under disaster conditions." ${ }^{43}$ Specifically, the Code would "replace[] the existing State Council of Civil Defense" with PEMA; expand the "state's role [in] . . . 1977).

${ }^{36}$ S. Journal, 161st Gen. Assemb., Reg. Sess., vol. 2, at 894 (Pa.

${ }^{37} \mathrm{Id}$.

${ }^{38}$ S. Journal, 161st Gen. Assemb., Reg. Sess., vol. 1, at 182 (Pa. 1978).

3935 PA. CONS. STAT. § 7503(2) (1978).

${ }^{40}$ S. Journal, 161st Gen. Assemb., Reg. Sess., vol. 1, at 182 (Pa. 1978).

${ }^{41}$ H. Journal, 161st Gen. Assemb., Reg. Sess., vol. 5, at 3663-64 (Pa. 1978).

${ }^{42} I d$.

${ }^{43} I d$. 
Volume 6 Issue 2

Spring 2012

develop[ing] and maintain[ing] a comprehensive program of emergency management activities that supplements, facilitate[s] and provide[s] direction when needed to local efforts before, during and after" disaster emergencies; and, renew the state's responsibility for requesting and procuring "federal resources to deal with emergencies." ${ }^{44}$ As in the Senate, no member of the House rose to register a complaint with respect to the expansive powers bestowed upon the Governor.

As the Bill proceeded through Committee, it was subject to multiple considerations in both the House and Senate, and amendments were proposed and approved. However, through seven versions - Printer's Numbers: 1306 (original), 1434, 1559, 1616, 1642, 2107, and 2213 (final) - the only significant change to Section 7301 came early in the process. Subsection (c) of 7301 was altered to extend the duration of the period of the Governor's declared disaster emergency from 30 days to 90 days. ${ }^{45}$ This is significant insofar as a shorter period is perceived by the National Governors Association (NGA) to constitute a "limitation[] on emergency powers." ${ }^{46}$ The NGA notes that ten states require that emergency declarations expire in less than 30 days, 16 states do not permit emergency declarations to exceed 30 days, and just 5 states allow emergency declarations to last 60 days or more. ${ }^{47}$ Pennsylvania's Governor has the authority to declare one of the longest states of emergency of any governor in the United States.

Ultimately, and without a single challenge to the contemplated powers granted to the Governor, the House ${ }^{48}$ and Senate $^{49}$ both unanimously approved the Bill. Then-Governor Milton Shapp signed the Bill into law on

${ }^{44} I d$.

${ }^{45}$ See S. 1104, 161st Gen. Assemb., Reg. Sess. (Pa. 1978).

${ }^{46}$ NGA, GOVERNOR's GUIDE, supra note 5.

${ }^{47} I d$. at 15 .

${ }^{48}$ H. Journal, 162nd Gen. Assemb., vol. 5, at 3662-63 (Pa. Nov. 14, 1978) (the vote was 190-0).

${ }^{49}$ S. Journal, 162nd Gen. Assemb., vol. 2, at 1167 (Pa. Nov. 15, 1978) (the vote was $47-0$ ). 
November 26, $1978 .^{50}$ The Code has been amended on numerous occasions since its enactment. Notably, however, Section 7301 was amended just once in July 1988. The amendment in question pertained to Subsection (f)(4) of 7301 and clarified - as well as arguably expanded - the Governor's commandeering power. The Subsection's language granting the Governor authority to commandeer or utilize any private property, if necessary, to cope with [a] disaster emergency was amended to grant the Governor authority to "commandeer or utilize any private, public or quasi-public property . . .." ${ }^{51}$

\section{Checks on and Challenges to the Pennsylvania Governor's EMERgenCy MANAgeMent POWERS}

Notwithstanding the apparent breadth of gubernatorial emergency management powers, "[a governor's] [e]mergency powers are not absolute."52 For instance, a governor cannot act in such a manner as to violate her state constitution or other statutes. ${ }^{53}$ To assure that "the response to $\mathrm{a}[\mathrm{n}] \ldots$ emergency is not impaired by legal uncertainty and that citizens are protected

${ }^{50}$ See S. JOURNAL, 161st Gen. Assemb., supra note 35.

5135 PA. CONS. STAT. § 7301(f)(4) (2011).

${ }^{52}$ NGA, GOVERNOR's GUIDE, supra note 5.

${ }^{53}$ Furthermore, the Pennsylvania Governor, along with all other state governors, is limited by the United States Constitution, federal statutes, and Supreme Court precedent. Federal statutes and regulations trump state statutes and regulations, and "[g]overnors ... do not have the authority to waive federal statutes or regulations." NGA, GOVERNOR's GUIDE, supra note 5, at 15. Even in times of crisis, governors must request waivers of statutes or regulations from relevant federal agencies. Equally true, state governors are bound by the decisions of the Highest Court in the Land. For instance, in Perpich v. Department of Defense, the Supreme Court held that the plain language of Article I of the Constitution established that Congress could authorize members of the National Guard of the United States to be ordered to active duty for purposes of training outside the country without the consent of state governors. 496 U.S. 334 (1990). 
Volume 6 Issue 2

Spring 2012

from arbitrary government action, ${ }^{154}$ it is important to understand not only the conceded breadth of a governor's powers, but also the existence and function of checks on those powers. This Part will explore four limiting factors as they relate to the emergency management powers of the Governor of Pennsylvania: (A) qualified suspension of laws, (B) separation of powers, (C) judicial review, and (D) the scope of an emergency.

\section{A. SUSPENSion OF Regulatory STATUtes}

Subsection (f)(1) of 7301 grants the Governor authority to "suspend the provisions of any regulatory statute prescribing the procedures for conduct of Commonwealth business," as exigent circumstances may require. ${ }^{55}$ This triggers numerous questions: What is a so-called regulatory statute? Are regulatory statutes a narrowly defined category or subset of statutes? Is the Governor thus constrained to suspending only provisions of regulatory statutes and powerless to suspend provisions of other, ostensibly "nonregulatory" statutes? Not surprisingly, the Emergency Management Services Code does not furnish a definition of "regulatory statute." ${ }^{56}$

Pennsylvania case law provides insight regarding the meaning of "regulatory statute." In Commonwealth v. CSX Transportation, Inc., the Superior Court stated: "[g]enerally, a 'regulatory statute' is the result of the exercise of the state's police power to enact regulations to promote the public health, morals or safety, and the general well-being of the community." ${ }^{57}$ The court deemed the Fish and Boat Code to be a regulatory statute given its

54 John A. Bozza, Crisis in the Making: What is Wrong with Pennsylvania Public Health Law, 3 Pitt. J. Envtl. Pub. Health L. 1, 3 (2009) (emphasis added).

5535 PA. CONS. STAT. § 7301(f)(1) (proposed 1988) (emphasis added).

${ }^{56}$ In fact, a search of the entire Pennsylvania statutes yields only nine other references to "regulatory statute." Again, the term is not defined in connection with any of these references. One statutory section, establishing Commonwealth Court jurisdiction over "regulatory criminal cases," will receive further treatment herein. See 42 PA. CONS. STAT. § 762 (2011).

57639 A.2d 1213, 1214 (Pa. Super. Ct. 1994). 
manifest purpose to prevent the pollution of waters in order to promote and protect fishing interests. There are other asserted examples of regulatory statutes in addition to the Fish and Boat Code. In Commonwealth v. Reed, the court reasoned that "[b]ecause the legislature empowered the [Pennsylvania Game] Commission to protect, propagate, manage, and preserve the game or wildlife of the Commonwealth, it is clear that [the Game and Wildlife Code] is a regulatory statute ...." ${ }^{58}$ Further, describing a "regulatory statute" as marked by an "overall character as a statute regulating certain conduct within the state," the Commonwealth Court "conclude[d], after reviewing the entire [Clean Streams Law] and its purposes, that [it] is a 'regulatory statute."'59 To clarify, the Pa Op Attorney General opined that "[t]he Water Obstructions Act is a 'regulatory statute,' the purposes of which are to preserve the public's right of navigation; to protect life and property from hazards created by unsupervised placement of water obstructions; to control the obstruction of flood flows; and to protect the regimen of streams." ${ }^{10}$

Section 762 of the Judicial Code warrants further exploration, especially with regard to its reference to regulatory statutes. The Section states:

[T]he Commonwealth Court shall have exclusive jurisdiction of appeals from final orders of the courts of common pleas in ... criminal actions or proceedings for the violation of any ... regulatory statute administered by any Commonwealth agency subject to Subchapter A of Chapter 5 of Title 2 (relating to practice and procedure of Commonwealth agencies). The term "regulatory statute" as used in this subparagraph does not include any provision of Title 18 (relating to crimes and offenses). ${ }^{61}$

${ }^{58}$ Commonwealth v. Reed, 696 A.2d 199, 201 (Pa. Super. Ct. 1997).

${ }^{59}$ Commonwealth v. Tyson, 427 A.2d 283, 285 (Pa. Commw. Ct. 1981).

${ }^{60} 1977$ Pa. Op. Att'y Gen. 73, at 7.

${ }^{61} 42$ PA. CONS. STAT. § 762(a)(2)(ii) (2011). 
Volume 6 Issue 2

Spring 2012

It can be inferred from this language that regulatory statutes are statutes that are primarily, if not exclusively, administered by Commonwealth agencies. Does it follow that these regulatory statutes comprise a unique or narrower class of statutes, traditionally the province of Commonwealth agencies? Furthermore, can the term "Commonwealth agencies" be read to mean "administrative agencies" in the traditional sense, ${ }^{62}$ such that the Governor truly is constrained to suspending certain regulatory statutes as administered by certain administrative agencies? Not necessarily.

Commonwealth agencies, within the meaning of Section 762 of the Judicial Code, are those agencies subject to the Administrative Law and Procedure provisions of the Pennsylvania Statutes. ${ }^{63}$ Section 501(a) of the pertinent Subchapter A states: "[t]his subchapter shall apply to all Commonwealth agencies." ${ }^{64}$ Elsewhere in Title 2, the term "Commonwealth agencies" is defined to include "[a]ny executive agency or independent agency." ${ }^{15}$ The term "executive agencies" is further defined to include "[t]he Governor and the departments, boards, commissions, authorities and other officers and agencies of the Commonwealth government," while the term "independent agencies" is further defined to include "[b]oards, commissions, authorities and other agencies and officers of the Commonwealth government [that] are not subject to the policy supervision and control of the Governor." ${ }^{\text {"6 }}$ Even a cursory evaluation of these definitions demonstrates that the term

${ }^{62}$ See BLACK's LAW DiCTIONARY 72 (9th ed. 2009) (Defining the term "administrative agency" as "a governmental body with the authority to implement and administer particular legislation.”).

${ }^{63} 2$ PA. CONS. STAT. § 762(a)(2)(ii) (2011).

${ }^{64} 2$ PA. CONS. STAT. $§ 501$ (a) (2011) (emphasis added).

${ }^{65} 2$ PA. CONS. STAT. $\S 101$ (2011).

${ }^{66}$ Id. An example of an independent commission would be the Pennsylvania Fish and Boat Commission. "The Commission is an independent governmental commission. The Commission is considered an independent agency and a 'Commonwealth Agency' for the purposes of Subchapter A of Chapter 5 of Title 2 (relating to practice and procedure of Commonwealth agencies)." Commonwealth v. CSX Transp., Inc., 639 A.2d 1213, 1214 (Pa. Super. Ct. 1994) (citations omitted). 
"Commonwealth agencies" is quite broad and encompasses considerably more than administrative agencies as traditionally understood. ${ }^{67}$ Unfortunately, this offers little to clarify what is a regulatory statute, who or what administers a regulatory statute, and therefore what, if any, functional limitation is imposed on the Governor by the Code's language in Subsection (f)(1) of 7301.

Section 762 of the Judicial Code also states: "The term 'regulatory statute' as used in this subparagraph does not include any provision of Title 18 (relating to crimes and offenses)." ${ }^{\prime 68}$ Does this language suggest that criminal statutes, as contained in the Pennsylvania Crimes Code, ${ }^{69}$ are not regulatory statutes and thus beyond the reach of the Governor's suspension powers? Again, the answer is not entirely clear. The quoted language is selflimiting in that it specifies "as used in this subparagraph." In other words, it cannot be fairly concluded from this language that criminal statutes are distinct from regulatory statutes as the latter term is used in Subsection (f)(1) of 7301 or, for that matter, as that term is used anywhere else throughout the Pennsylvania Statutes. However, in United States v. Conley, the United States District Court for the Western District of Pennsylvania stated that Section 5513 of the Crimes Code (relating to the conduct of an illegal gambling business) is a "criminal statute, rather than a regulatory statute." ${ }^{70}$ Therefore,

67 See also Other StATE Agencies, Pennsylvania STATE GOVERNMENT HOMEPAGE, http://www.portal.state.pa.us/portal/server.pt? open $=512 \&$ objID $=20598 \&$ PageID $=1052160 \&$ mode $=2$ (last visted Jan. 25, 2012). A perusal of the website reveals a comprehensive list of over 30 Commonwealth "agencies," along with a variety of other "offices," "commissions \& councils," "boards," and "bureaus \& authorities." While the list of agencies includes full-on administrative agencies such as the Department of Health and PEMA, it also includes clearly non-administrative entities such as "Corrections," the "Pennsylvania State Police," and the state's "General Counsel."

${ }^{6} 42$ PA. CONS. STAT. $§ 762$ (a)(2)(ii) (2011).

${ }^{69} 18$ PA. CONS. STAT. § 101 (2011).

${ }^{70} 833$ F. Supp. 1121, 1160 (W.D. Pa. 1993), vacated on other grounds, 37 F.3d 970 (3d Cir. 1994). "Section 5513 is found in the Pennsylvania 


\section{Volume 6 Issue 2}

Spring 2012

it may be a tenable inference that the Governor may not suspend the provisions of any criminal statute included in the Pennsylvania Crimes Code.

Whatever varying conclusions may be drawn from the foregoing discussion, it is clear that the Governor is authorized to suspend provisions of a regulatory statute administered by a Commonwealth agency. Pennsylvania's Disease Prevention and Control Law ${ }^{71}$ (DPCL) is a prime example of a regulatory statute administered by a Commonwealth agency. The final authority to implement and enforce provisions of the DPCL is vested in the State Department of Health. ${ }^{72}$ The purpose of the DPCL is the prevention and control of communicable and non-communicable diseases. ${ }^{73}$ As such, the law is indisputably a "result of the exercise of the state's police power to enact regulations to promote the public health ...." ${ }^{74}$ These observations contribute to the conclusion that the Governor could almost certainly exercise his emergency management powers in suspending provisions of the DPCL.

The DPCL permits the State Advisory Health Board to issue rules and regulations regarding, among other things, "the enforcement of isolation, quarantine and other control measures," and "the immunization and vaccination of persons and animals. ${ }^{175}$ Additionally, municipalities with their

Criminal Code and is defined there as a first degree misdemeanor. The General Assembly of the Commonwealth defined Section 5513(a) as a crime, not a regulatory provision." $I d$.

7135 PA. CONS. STAT. $\S$ 521.1-.21 (2011).

7235 PA. CONS. STAT. § 521.3(b) (2011). Local boards of health and local departments of health, subject to the supervision of the State Department of Health, are directed to prevent and control disease locally, including outbreaks in schools. Id. at $\S 521.3(\mathrm{a})$. The State Secretary of Health, upon a finding of inadequate prevention and control measures adopted by these local boards and departments, may direct the State Department of Health to intervene. Id. at $\S 521.3(\mathrm{c})$.

7335 PA. CONS. STAT. § 521.3(b) (2011).

${ }^{74}$ Commonwealth v. CSX Transp., Inc., 639 A.2d 1213, 1214 (Pa. Super. Ct. 1994).

7535 PA. CONS. STAT. §§ 521.16(a)(5)-(6) (2011). 
own boards of health or departments of health may enact ordinances or issue rules and regulations "relating to disease prevention and control." Presumably, Subsection (f)(1) of 7301 empowers the Governor to suspend any-and-all such ordinances, rules, or regulations.

This is not to suggest that the Governor could abjectly ignore procedural due process protections as they relate to the activities of quarantine or isolation. DPCL Sections 521.7 and 521.11(a.2) provide for a hearing by a court when individuals suspected of being ill with communicable diseases refuse to submit to "examination and diagnosis" and "treatment." Individuals who refuse to be examined may be "committed by the court to an institution . . . " ${ }^{77}$ Similarly, when individuals refuse treatment, "the court shall . . order such person to be committed to an appropriate institution or hospital ...." Consequently, there does not appear to be support for the Governor, even during a declared disaster emergency, to attempt to circumvent procedures engaging the courts in this active role. ${ }^{79}$

7635 PA. CONS. STAT. § 521.16(c) (2011).

7735 PA. CONS. STAT. $\S 521.7$ (2011).

7835 PA. CONS. STAT. $\S$ 521.11(a.2) (2011).

${ }^{79}$ Cf. Counterterrorism, Planning, Preparedness and Response Act, 35 PA. CONS. STAT. $\$ 2140.301$ (2011) (Authorizing the Governor to "temporarily isolate or quarantine an individual or groups of individuals through a written order if delay in imposing the isolation or quarantine through judicial proceedings ... would significantly jeopardize the ... ability to prevent or limit the transmission of a contagious or potentially contagious disease to others."). Of particular note, an order to isolate or quarantine issued without prior judicial approval "shall not require a declaration of disaster emergency by the Governor in order to be effective." Id. See THE MODEL State EMERGENCy HeAlth Powers ACT (MSEHPA) (Ctr. for Law and the Pub.'s Health 2004), available at http://www.publichealthlaw.net/MSEHPA/ MSEHPA.pdf. The MSEHPA provides "conditions and principles" for protecting the substantive rights of isolated or quarantined individuals, stating "[i]solation and quarantine must be by the least restrictive means necessary to prevent the spread of a contagious or possibly contagious disease to others ..." MSEHPA $\S 604(b)(1)$. It is worth noting that in enacting the 
Volume 6 Issue 2

Spring 2012

Finally, it is useful to look to other state's emergency management laws to compare the suspension powers granted to those states' governors with the suspension powers granted to Pennsylvania's Governor. This analysis reveals that the majority of governors are specifically authorized to suspend "regulatory statutes" or the "provisions of any regulatory statute." ${ }^{80}$ Only seven states authorize their governors to suspend any statute or law whatsoever. ${ }^{81}$ Finally, the remaining four states appear to constrain their

Counterterrorism Act, the PA General Assembly adopted neither the "conditions and principles" nor the "least-restrictive-means" requirement of the MSEHPA.

${ }^{80}$ See, e.g., CAL. GOV'T CODE $\S 8571$ (1990) (Noting that "[d]uring a state of war emergency or a state of emergency the Governor may suspend any regulatory statute, or statute prescribing the procedure for conduct of state business, or the orders, rules, or regulations of any state agency, including subdivision (d) of Section 1253 of the Unemployment Insurance Code, where the Governor determines and declares that strict compliance with any statute, order, rule, or regulation would in any way prevent, hinder, or delay the mitigation of the effects of the emergency."). See also LA. REV. STAT. ANN. § 29:724 (1993) (describing that "in addition to any other powers conferred upon the governor by law, he may ... [s] uspend the provisions of any regulatory statute prescribing the procedures for conduct of state business, or the orders, rules, or regulations of any state agency, if strict compliance with the provisions of any statute, order, rule, or regulation would in any way prevent, hinder, or delay necessary action in coping with the emergency."). See generally the similar laws of Alaska, Arkansas, Colorado, Delaware, Florida, Georgia, Illinois, Indiana, Iowa, Kansas, Mississippi, Montana, Nebraska, North Dakota, Texas, and West Virginia similarly reference their governors' ability to suspend "regulatory statutes" during emergencies.

${ }^{81}$ See, e.g., CONN. GEN. STAT. § 28-9(a) (1975) (which notes that "the governor is authorized and empowered to modify or suspend in whole or in part ... any statute, regulation or requirement or part thereof whenever the Governor finds such statute, regulation or requirement, or part thereof, is in conflict with the efficient and expeditious execution of civil preparedness functions or the protection of the public health"); see also N.Y. EXECUTIVE LAW § 29-a (1978) (which provides that "the governor may by executive order temporarily suspend specific provisions of any statute, local law, 
governor's suspension powers. For example, while Michigan's governor may "[s]uspend a regulatory statute, order or rule," the state legislature was explicit that this power does not extend to "the suspension of criminal process and procedures." 82 Idaho, South Carolina, and South Dakota only permit their governors to suspend "the provisions of any regulation," "the provisions of existing regulations," and "any rules of any state agency," respectively. ${ }^{83}$ In these states' emergency management laws, any reference to the suspension of statutes, regulatory or otherwise, is absent.

\section{B. Separation of Powers}

The legal principles embodied in the doctrine of the separation of powers operate to fundamentally curb gubernatorial overreaching. "The separation of governmental powers into legislative, executive, and judicial is provided for in practically all the American state constitutions," and is designed to preclude one branch or actor representing that branch from interfering with or encroaching upon the basic powers of another branch or actor representing that branch. ${ }^{84}$ In the context of the exercise of emergency management powers, it has been argued that state governors, embodying executive power, on occasion invade the spheres of the legislature or the courts. What is the scope of the Pennsylvania Governor's emergency management powers vis-à-vis the Pennsylvania General Assembly and the state's system of courts?

ordinance, or orders, rules or regulations or parts thereof, of any agency during a state disaster emergency, if compliance with such provisions would prevent, hinder, or delay action necessary to cope with the disaster." Connecticut and New York are joined by Arizona, Maine, Maryland, Missouri, and Tennessee in granting apparently broad suspension powers to their governors.

${ }^{82}$ MiCH. COMP. LAWS $§ 30.405($ a) (1990).

${ }^{83}$ IdAHO CODE ANN. § 46-1008(5)(a) (2006); S.C. CODE ANN. REGS. $\S$ 25-1-440(a)(3) (2008); S.D. CODIFIED LAWS $§ 34-48 A-5$ (2004).

8416 C.J.S. Constitutional Law $\S 215$ (2009). 


\section{The Pennsylvania General Assembly}

As discussed in the preceding section, the Governor is authorized to "[s]uspend the provisions of any regulatory statute prescribing the procedures for conduct of Commonwealth business," if he deems it necessary to cope with an emergency. ${ }^{85}$ Yet, the Governor's action in suspending the operation of laws enacted by the General Assembly constitutes something beyond the exercise of traditional executive powers. The Pennsylvania Constitution states: "No power of suspending laws shall be exercised unless by the Legislature or by its authority." ${ }^{86}$ While it is true that such an action is countenanced by authorizing legislation, the exercise of such authority could be used to countermand, at least for a time, any number of laws adopted by the General Assembly. Hence, in exercising this particular emergency management power, the Governor can potentially intrude upon the legislative function.

Nevertheless, an unassailable tenet of the separation-of-powers doctrine is that the "Legislative branch of government creates laws," and that the Governor is bound to "execute the laws and not to create or interpret them." ${ }^{87}$ Not only does the General Assembly create the laws, but it is also vested with the power to amend or repeal laws. ${ }^{88}$ Accordingly, the General Assembly, should it see fit, could amend or repeal Subsection (f)(1) of 7301 and thereby "dial back" the Governor's ability to suspend laws during declared disaster emergencies. Moreover, Subsection (c) of 7301 limits the Governor's ability to declare and maintain a state of disaster emergency by granting the General Assembly the power to terminate a state of emergency at any time by concurrent resolution. ${ }^{89}$ Presumably, if the General Assembly disfavors the

8535 PA. CONS. STAT. § 7301(f)(1) (1988).

${ }^{86}$ PA. CONST. art. I, § 12.

${ }^{87}$ Shapp v. Butera, 348 A.2d 910, 914 (Pa. Commw. Ct. 1975).

8835 PA. CONST. art. II, $\S 1$.

${ }^{89}$ See 35 PA. CONS. STAT. $\S 7301$ (c) (2011) (The NGA characterizes the ability of a legislature to intervene to terminate a declaration of a state of emergency as a "limitation on emergency powers," and notes that in at least 
Governor's suspension of a law or laws, it could override that suspension by undoing the declaration of a disaster emergency.

Finally, consider that Subsection (f)(1) of 7301 also authorizes the Governor to "[suspend] ... the orders, rules or regulations of any

Commonwealth agency ...." As noted earlier, "Commonwealth agency" is a defined term which explicitly excludes "the General Assembly and its officers and agencies." 91 From this it may be concluded that the internal operating rules or the investigations and studies of the General Assembly and its legislative committees are beyond the reach of the Governor's suspension powers. As one example, the Pennsylvania Statutes call for the establishment of "a continuing joint legislative commission, to be known as the Joint State Government Commission," comprised of members of the House of Representatives and the Senate. ${ }^{92}$ The Commission has the "power" and "duty" to "make such investigations and studies and to gather such information as may be deemed useful to the General Assembly and the standing committees of the Senate and the House of Representatives." 93 The Commission would clearly be an entity consisting of officers of the General Assembly, and thus its activities arguably would be immune from the Governor's interference.

12 states the legislature is empowered to do so.). NGA, GOVERNOR's GUIDE, supra note 5 , at $14-15$.

9035 PA. CONS. STAT. $\S 7301(f)(1)(2011)$.

91 See 2 PA. Cons. STAT. § 101 (2011) (defining the term "Commonwealth agency" to cover any "executive agency" or "independent agency." According to the statutory definitions, the term "executive agency ... does not include ... the General Assembly and its officers and agencies ...." The term "independent agency ... does not include ... the General Assembly and its officers and agencies.").

9246 PA. COns. Stat. $§ 65$ (2011); see also The Joint StATE GOVERNMENT COMMISSION, http://jsg.legis.state.pa.us/ (last visited Apr. 15, 2010).

9346 PA. CONS. STAT. § 66(a) (2011). 
Volume 6 Issue 2

Spring 2012

\section{The Pennsylvania Courts}

The Pennsylvania Constitution provides: "[t]he judicial power of the Commonwealth shall be vested in a unified judicial system consisting of the Supreme Court, the Superior Court, the Commonwealth Court, courts of common pleas, community courts, ... [and] such other courts as may be provided by law and justices of the peace." ${ }^{94}$ The judiciary is a coequal branch of the Commonwealth government. ${ }^{95}$ While the General Assembly may create "additional courts or divisions of existing courts" and may abolish "any statutory court or division thereof," $"$ the General Assembly may not exercise any power specifically entrusted to the judiciary. ${ }^{97}$

Likewise, the Governor is limited in his authority with respect to the courts. The Pennsylvania Constitution grants the Pennsylvania Supreme Court "the power to prescribe general rules governing practice, procedure and the conduct of all courts, ... and the administration of all courts and supervision of all officers of the Judicial Branch ...." ${ }^{98}$ In First Judicial District of Pennsylvania v. PHRC, the PA Supreme Court averred:

[I]nterference in the operation of courts is prohibited by the separation of powers doctrine. The supreme court has the sole power and the responsibility to supervise the

${ }^{94}$ PA. CONST. art. V, $§ 1$.

${ }^{95}$ Commonwealth v. Sutley, 378 A.2d 780, 783 (Pa. 1977) (Noting the well-established principle that "the judicial branch is not subordinate to the other branches of government but is co-equal, distinct, and independent.").

${ }^{96}$ PA. CONST. art. V, $\S 8$.

${ }^{97}$ Kremer v. State Ethics Comm'n, 469 A.2d 593, 595 (Pa. 1983) (holding that "[u]nder the doctrine of separation of powers, the legislature may not exercise any power specifically entrusted to the judiciary, which is a co-equal branch of government" (citations omitted)).

98 PA. CONST. art. V, §10(c). The Pennsylvania Supreme Court, pursuant to Article V, Section 10 of the Constitution, recently adopted rules for maintaining court operations during a pandemic, natural disaster, or other public emergency; see also 201 PA. CODE $§ \S 1950-1954$ (2011). 
"practice, procedure, and the conduct of all courts." [T] he executive branch of government ... may [not] constitutionally infringe on this judicial prerogative. ${ }^{99}$

Consequently, despite the Emergency Management Services Code authorizing the Governor to "suspend the ... orders, rules or regulations of any Commonwealth agency," ${ }^{100}$ as well as "[t]ransfer the direction, personnel or functions of Commonwealth agencies or units thereof," ${ }^{101}$ it is evident that the PA Supreme Court has "sole" power over practically all aspects of judicial administration. This reading is further supported by the fact that the term "Commonwealth agency" as employed in the Code does not include the courts. $^{102}$

An example of a critical rule adopted by the Pennsylvania Supreme Court is the "speedy trial" or "prompt trial" rule. ${ }^{103}$ The prompt trial rule was recommended by the Criminal Procedural Rules Committee, ${ }^{104}$ an advisory arm to the court, pursuant to the court's ruling in Commonwealth $v$. Hamilton. ${ }^{105}$ In that case, the court held that Pennsylvania's "two term" or "180 day" rule was inadequate to protect the interests of those whom the Commonwealth accuses of criminal violations. ${ }^{106}$ Currently Rule 600, the

99727 A.2d 1110, 1112 (Рa. 1999).

10035 PA. CONS. STAT. § 7301(f)(1) (2011).

10135 PA. CONS. STAT. $\S 7301(f)(3)$ (2011).

1022 PA. CONS. STAT. $\S 101$ (2011).

${ }^{103}$ See PA. R. CRIM. P. 600 (2011).

${ }^{104}$ See The United Judicial System OF PENNSYlvania, available at http://www.courts.state.pa.us/T/BoardsCommittees/CrimProcRules/ (last visited Apr. 15, 2010).

105297 A.2d 127, 128 (Pa. 1972).

${ }^{106}$ See id. The court criticized the rule, which provided for discharge from imprisonment of any accused who had not been tried during the second term after his commitment, unless the delay happened on an application of or with the assent of the accused. This discharge from imprisonment, however, did not bar prosecution of the charges and only admitted the defendant to bail 
Volume 6 Issue 2

Spring 2012

"prompt trial" rule, provides reasonable time periods within which trials must commence. ${ }^{107}$ As discussed above, the Pennsylvania Supreme Court possesses the sole power to adopt such rules. Furthermore, the court is not a "Commonwealth agency" as defined by the Pennsylvania Statutes. Consequently, it would appear that the Governor, even during a declared disaster emergency, could not suspend or otherwise interfere with this or any other court rule. ${ }^{108}$

\section{Judicial Review}

While research into the availability and application of judicial review to the Governor's actions yields sparse results, some record of review exists with regard to the Governor's issuance of executive orders. The Pennsylvania Commonwealth Court in National Solid Wastes Management Association v. Casey ${ }^{109}$ noted that only executive orders which "serve to implement or supplement the constitution or statutes," are subject to judicial review. ${ }^{110}$

until the cause was ultimately brought to trial. Furthermore, the rule was designed to apply only to committed defendants awaiting trial and provided no relief for defendants who were already on bail status but were being denied a speedy trial. $I d$. at 130-31. According to the court, the rule was inadequate because it resulted in "inordinate delay between the institution of charges and the trial, ... [was] effective only when the accused demand[ed] his release prior to trial, ... [and] fail[ed] to require dismissal of the charges with prejudice." Id. at 131 .

${ }^{107}$ PA. R. CRIM. P. 600 (2012).

${ }^{108}$ But see People v. Wright, 748 N.Y.S.2d 199 (N.Y. Crim. Ct. 2002) (holding that the New York Governor could suspend certain "speedy trial" requirements of the State's Criminal Procedure Law during the declared state of emergency following the September 11, 2001 terrorist attacks); see also People v. Haneiph, 745 N.Y.S.2d 405 (N.Y. Crim. Ct. 2002) (holding the same and thus refusing to dismiss defendant's charges).

109580 A.2d 893 (Pa. Commw. Ct. 1990).

${ }^{110}$ See id. at 897-98 (noting that the court identified three types of executive orders: (1) formal, ceremonial, political orders, usually issued as proclamations; (2) orders which communicate to subordinate officials requested or suggested directions for the execution of the duties of the 
Typically, actions invoking such review challenge the executive order on the grounds that the Governor issued it in the absence of either constitutional authority or a legislative mandate. ${ }^{111}$ Accordingly, what is the proper standard and scope of judicial review for executive orders?

"An executive order issued by the Governor which serves to implement or supplement the Constitution or a statute has the force of law, and therefore may be characterized and treated as an administrative regulation, at least for purposes of judicial review." ${ }^{112}$ A reviewing court will ordinarily afford considerable weight and deference to an administrative agency's promulgation of regulations pursuant to the statute it administers. "Our standard of review over regulations is very limited. We will not substitute our judgment for the agency's and will not strike down regulations unless a clear abuse of discretion is shown or the agency has exceeded its statutory powers." ${ }^{113}$ If the Governor's executive order is analogous to an administrative regulation (for purposes of judicial review), it is reasonable to surmise that the review of such an order will be limited and highly deferential.

The sufficiency of the Pennsylvania Governor's executive order declaring a disaster emergency and the related exercise of his suspension powers were addressed by the Commonwealth Court in In re Farrow. ${ }^{114}$ In that case, Petitioner Paula Brown challenged the Governor's extension of a statutorily mandated filing time for nomination petitions by his issuance of an

Executive Branch of government; and (3) orders which serve to implement or supplement the constitution or statutes).

${ }^{111}$ Id. at 898 .

11236 Standard Pennsylvania Practice $§ 166: 77$ (2010) (citing Nat'l Solid Wastes Mgmt. Ass'n v. Casey, 580 A.2d 893 (Pa. Commw. Ct. 1990)).

${ }^{113}$ Brocal Corp. v. Commonwealth, Dep't of Transp., 528 A.2d 114, 121 (Pa. 1987); see also 36 Standard PenNSYlvania PRACTICE $§ 166: 342$ (2010).

114754 A.2d (Pa. Commw. Ct. 2000). 
Volume 6 Issue 2

Spring 2012

executive order due to a "sudden and severe winter storm." ${ }^{115}$ Brown asserted that the Governor lacked the requisite authority because "there was no legitimate emergency" and the order itself "did not provide that a 'State of Emergency' was declared throughout the State of Pennsylvania."116

The Governor filed a petition to intervene, which the court granted. ${ }^{117}$ As justification for the extension of the filing deadline, the Governor cited Section 7301(f)(1) of the Emergency Management Services Code as authorizing the "suspen[sion] [of] the provisions of any regulatory statute prescribing the procedures for conduct of Commonwealth business" during a state of emergency. ${ }^{118}$ The court, while conceding that the Governor's executive order did not explicitly state that he was declaring a "State of Emergency," assumed a highly deferential posture and found that the order "did in fact [declare such an emergency] because it contained all the requirements to so declare a state of emergency." ${ }^{119}$ The court was satisfied that the Governor had discerned that a disaster emergency existed and that, as a result of the emergency conditions, it was "necessary to extend the filing deadline for all nomination petitions by 24 hours in order to give all candidates a fair and reasonable opportunity to file their petitions." ${ }^{120}$ Deferring to the Governor's legislatively authorized power to issue an executive order declaring a disaster emergency and to exercise his suspension

${ }^{115}$ See id. at 33-34 (noting that Brown specifically objected to the nomination petition filed by James Farrow for the Office of State Representative of the 162nd District in the Democratic Primary to be held on April 4, 2000. Nomination petitions were required to be filed no later than 5:00 PM on January 25, 2000, pursuant to the Election Code, 25 Pa. Cons. Stat. § 2873; Farrow filed his nomination petition on January 26, 2000, beyond the original deadline but within the extension granted by the Governor).

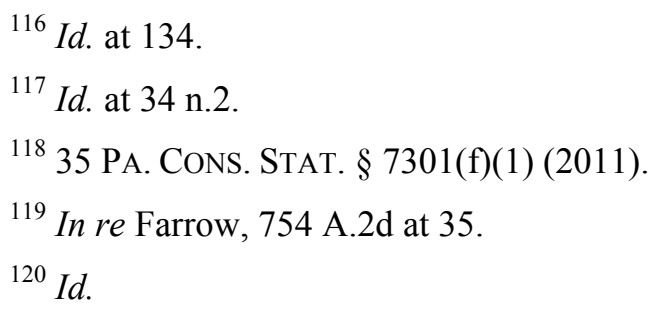


powers in extending the filing deadline, the court denied Brown's petition. ${ }^{121}$ While the Commonwealth Court stopped short of outlining in concrete terms the parameters of its review, it acknowledged and fulfilled its duty to review the Governor's actions. ${ }^{122}$ This case demonstrates that, when called up to do so, Pennsylvania courts will not abdicate their responsibility to review the actions of the Governor in connection with a disaster emergency and that review will likely be limited in scope and highly deferential.

\section{SCOPE OF THE DISASTER}

The Pennsylvania Code permits the Governor to declare a disaster emergency "upon finding that a disaster has occurred or that the occurrence or the threat of a disaster is imminent." ${ }^{123}$ The Code defines "disaster" to include "[a] man-made disaster, natural disaster or war-caused disaster." ${ }^{124}$ Of interest, the Code discusses and defines a "local emergency" as something separate and apart from other types of disaster emergencies. "Local emergency" is defined as follows:

The condition declared by the local governing body when in their judgment the threat or actual occurrence of a disaster is or threatens to be of sufficient severity and magnitude to warrant coordinated local government action to prevent or alleviate the damage, loss, hardship or suffering threatened or caused thereby. A local emergency arising wholly or substantially out of a

\section{${ }^{121} I d$. at 36 .}

${ }^{122}$ See id. at 35 (noting that the Pennsylvania Election Code is a clear example of a regulatory statute); see also Commonwealth v. Wadzinkski, 422 A.2d 124, 127 (Pa. 1980) (referring to the Election Code as a regulatory statute in an action challenging the constitutionality of a provision imposing criminal sanctions upon a candidate who publishes a political advertisement referring to an opponent without first complying with prescribed notice requirements).

12335 PA. CONS. STAT. § 7301(c) (2011).

12435 PA. CONS. STAT. $\$ 7102$ (2011). Specific definitions are also provided for each of these three types of disasters. 
resource shortage may be declared only by the Governor, upon petition of the local governing body, when he deems the threat or actual occurrence of a disaster to be of sufficient severity and magnitude to warrant coordinated local government action to prevent or alleviate the damage, loss, hardship or suffering threatened or caused thereby. ${ }^{125}$

From this definition, it can be deduced that the primary responsibility and authority to declare a local disaster emergency rests with the local governing body. Findings by the Governor are not a condition precedent, and the local disaster emergency is declared without the imprimatur of a gubernatorial executive order. Furthermore, only under circumstances characterized by a "resource shortage"126 and only "upon petition of the local governing body" ${ }^{127}$ may the Governor intervene to declare a local disaster emergency.

The Governor can however, intervene on his own authority, with or without the petition of the local governing body. This could occur when the Governor arrives at an independent determination that the emergency, despite being localized, is of such a scale that it could inflict severe "damage, loss, hardship, or suffering" upon a "substantial number of citizens" and that the measures pursued by the local governing body are inadequate to meet the emergency. The Code's definition of "disaster emergency" suggests the Governor could declare such a state and intervene when "conditions ... [are] of such magnitude or severity as to render essential State supplementation of county and local efforts or resources exerted or utilized in alleviating the danger, damage, suffering or hardship faced." ${ }^{128}$

${ }^{125} I d$. (emphasis added).

126 See id. (defining "Resource shortage" as "[t]he absence, unavailability or reduced supply of any raw or processed natural resource, or any commodities, goods or services of any kind which bear a substantial relationship to the health, safety, welfare and economic well-being of the citizens of this Commonwealth").

${ }^{127} I d$.
${ }^{128} I d$. 


\section{Conclusions}

It is clear from the foregoing that governors across the states, including the Governor of Pennsylvania, while not given carte blanche to violate a statute or state constitution, undeniably have expansive emergency management powers. In the last ten years alone, numerous major natural and man-made disaster emergencies have prompted governors to exercise those powers. Unsurprisingly, the National Governors Association urges new and incoming governors to "learn quickly how to respond to emergency situations such as fires, floods, earthquakes, hurricanes, tornados, terrorist attacks, and pandemics." ${ }^{129}$ The NGA goes a step further, warning that a weak or flawed response to an emergency disaster "will likely [result in the governor] be[ing] held accountable and pay[ing] a price either in political capital or a loss of focus on his or her priority initiatives." ${ }^{130}$

Moreover, any perceived encroachment on emergency management powers has faced staunch collective opposition by the governors. For example, during much of 2009, the Department of Defense and the NGA were at odds over a legislative proposal that was to transfer, from governors to the Secretary of Defense, the authority to command National Guard and U.S. military units dispatched to states during disaster emergencies. ${ }^{131}$ The NGA expressed grave doubts about the proposal, saying that such a power transfer would "invite confusion on critical command and control issues, complicate interagency planning, establish stove-piped response efforts, and interfere with governors' constitutional responsibilities to ensure the safety

129 Barry Van Lare, Risk Management Challenges for the New Governor, NATIONAL GOVERNORS ASSOCIATION 1 (2007), available at http://www.nga.org/files/live/sites/NGA/files/pdf/OMCTRISKMANAGEME NT.PDF.

${ }^{130} I d$.

${ }^{131}$ See Reid Wilson, Governors Oppose DoD Emergency Powers, THE HILl, Aug. 10, 2009, available at http://thehill.com/homenews/ administration/54193-governors-oppose-dod-emergency-powers. 
Volume 6 Issue 2

Spring 2012

and security of their citizens." ${ }^{132}$ Despite this disagreement, on January 10, 2010 President Barack Obama issued Executive Order 13528 which created a Council of Governor's to advise the federal government on "(a) matters involving the National Guard of the various States; (b) homeland defense; (c) civil support; [and] (d) synchronization and integration of State and Federal military activities in the United States"; thus formalizing ongoing dialogue related to this potential shift in gubernatorial powers. ${ }^{133}$

While it presently appears that the State Constitution and the Emergency Management Services Code infuse Pennsylvania's Governor with extensive and wide-ranging emergency management powers, these powers are not without limitation. The doctrine of the separation of powers, the ability of the legislature to overturn a gubernatorial emergency declaration, the prospect of judicial review, and the qualified limitation of suspension authority to "regulatory statutes" as evidenced by the text of the suspension clause itself, collectively impose meaningful checks to prevent the exploitation of such powers by the Governor.

${ }^{132}$ Letter from Governor James H. Douglas and Governor Joe Manchin III to the Honorable Paul Stockton, Assistant Secretary of Defense for Homeland Defense and America's Security Affairs (Aug. 7, 2009), available at http:/www.nga.org/cms/home/federal-relations/nga-letters/ executive-committee-letters/col2-content/main-content-list/title_august-72009.html.

${ }^{133}$ Exec. Order No. 13528, 75 Fed. Reg. 2035 (Jan. 10, 2010), available at http://edocket.access.gpo.gov/2010/pdf/2010-705.pdf. 